\title{
TINGKAT BAGI HASIL DEPOSITO MELALUI VARIABEL INTERVENING DANA PIHAK KETIGA TERHADAP PEMBIAYAAN MUDHARABAH BANK SYARIAH ${ }^{1}$
}

\author{
Setiyoaji \\ Departemen Ekonomi Syariah- Fakultas Ekonomi dan Bisnis-Universitas Airlangga \\ Email: setiyoaji@feb.unair.ac.id \\ Imron Mawardi \\ Departemen Ekonomi Syariah- Fakultas Ekonomi dan Bisnis-Universitas Airlangga \\ Email: imron.mawardi@feb.unair.ac.id
}

\begin{abstract}
:
This study aims to determine the effect of profit sharing rates on deposits to third party funds and financing mudharabah sharia banks partially or simultaneously. The approach used is a quantitative approach by using the pathway analysis technique with three variables, namely the profit-sharing rate of deposits as ecogenous variable. Population in this study is the sharia bank industry registered in the statistics of Islamic banking published by the website of the Bank Indonesia. The sample used in this study as many as 60 samples with data from January 2012 until December 2016. Data collection is done by collecting financial statements of the sharia bank industry monthly period 2012-2016.
\end{abstract}

Keywords: Sharia banks, profit-sharing rates, third party funds, mudharabah financing

\section{PENDAHULUAN}

\section{Latar Belakang}

Bank syariah merupakan salah satu jenis bank umum yang kini juga telah beroperasi di Indonesia. Kehadiran bank syariah di Indonesia masih tergolong baru, namun kinerja bank syariah di Indonesia terus menunjukkan adanya peningkatan secara terus menerus selama sepuluh tahun terakhir yang ditandai dengan banyaknya peminat atau nasabah. Kondisi ini tidak lepas dari adanya dukungan dari tiga lembaga yang secara intensif diberikan kepada perkembangan bank syariah. Tiga lembaga tersebut adalah Bank Indonesia, Dewan Syariah Nasional-Majelis Ulama Indonesia (KAS-IAI) (Junaidi,2015). Perkembangan bank syariah di Indonesia mulai membaik secara kuantitas sejak adanya perubahan undang-undang Perbankan no.7 Tahun1992 menjadi undang-undang no.10 Tahun 1998. Perubahan itu semakin mendorong berkembangnya keberadaan sistem perbankan syariah di Indonesia.

Dalam perjalanan waktu, Bank Syariah yang pertama kali berdiri yaitu Bank Muamalat Indonesia terus melakukan pembenahan dalam hal perbankan syariah dan menerapkan prinsip syariah. Bank Muamalat berdiri atas prakarsa Majelis Ulama Indonesia (MUI) dan dukungan sekelompok pengusaha dan kaum cendekiawan Muslim, yang akan memulai kegiatan operasinya pada bulan Mei 1992. Gagasan tersebut berhasil mendapat tanggapan positif dari pemerintah dan masyarakat. Hal ini terbukti dengan adanya komitmen pengusaha untuk membeli saham

\footnotetext{
${ }^{1}$ Jurnal ini merupakan bagian dari skripsi Setiyoaji, NIM: 041114132, yang diuji pada tanggal 18 Juli 2018.
} 
perseroan. Selanjutnya pada acara silaturahmi yang diselenggarakan di Istana Bogor, BMI telat mendapat tambahan komitmen masyarakat Jawa Barat sehingga besarnya modal menjadi Rp 106 miliar. Oleh karena itu, Industri Perbankan Syariah harus terus memperkuat diri agar dapat meningkatkan peran dalam mengembangkan perekonomian di Indonesia. Industri perbankan syariah harus menjadi industri yang kuat, memiliki market share yang tinggi dan menjadi pilihan masyarakat.

Industri Perbankan Syariah yang merupakan bentuk kesadaran masyarakat muslim akan penerapan konsep syariah dalam bidang ekonomi seharusnya mampu menjadi pemain utama dalam industri perbankan, mengingat sebagian besar penduduk di Indonesia adalah muslim. Perkembangan perbankan syariah di Indonesia menunjukan adanya peningkatan pesat. Peningkatan tersebut dapat dilihat antara lain dari adanya perkembangan jumlah bank syariah. Pada periode antara tahun 1992-1998 hanya ada satu unit bank syariah, pada tahun 2005 bank syariah berkembang menjadi 20unit, yaitu 3 Bank Umum Syariah dan 17 Unit Usaha Syariah, dan hingga pada ntahun 2016 Bak Syariah berkembang pesat menjadi 34 yaitu 13 Bank Umum Syariah dan 21 Unit Usaha Syariah.

\section{Rumusan Masalah}

Berdasarkan uraian latar belakang diatas, maka rumusan masalah yang dapat diajukan pada penelitian ini adalah 1. Apakah tingkat bagi hasil deposito berpengaruh terhadap dana pihak ketiga di Bank Syariah?

2. Apakah dana pihak ketiga berpengaruh terhadap pembiayaan mudharabah Bank Syariah?

3. Apakah tingkat bagi hasil deposito berpengaruh terhadap pembiayaan mudharabah di Bank Syariah?

\section{Tujuan Penelitian}

Penelitian ini bertujuan untuk menjawab rumusan masalah yaitu mengetahui tingkat bagi hasil deposito bepengaruh terhadap dana pihak ketiga di Bank Syariah, Mengetahui dana pihak ketiga berpengaruh terhadap pembiayaan mudharabah Bank Syariah, mengetahui tingkat bagi hasil deposito berpengaruh terhadap pembiayaan mudharabah di Bank Syariah.

\section{LANDASAN PUSTAKA}

\section{Pengertian Bank Syariah}

Sistem keuangan dan perbankan islam merupakan bagian dari konsep yang lebih luas mengenai ekonomi islam, dimana tujuannya, sebagaimana yang dianjurkan oleh para ulama adalah memberlakukan sistem nilai dan etika islam ke dalam lingkungan ekonomi. Atas dasar etika inilah, maka keuangan dan perbankan islam bagi kebanyakan muslim bukan sekedar sistem transaksi komersial saja. Persepsi islam dan transaksi financial tersebut dipandanf oleh banyak kalangan 
Setiyoaji, et al/Jurnal Ekonomi Syariah Teori dan Terapan Vol. 6 No. 5 Mei 2019: 957-967; TINGKAT BAGI HASIL DEPOSITO MELALUI VARIABEL INTERVENING DANA PIHAK KETIGA TERHADAP PEMBIAYAN MUDHARABAH BANK SYARIAH

muslim sebagai suatu kewajiban agama. Kemampuan lembaga keuangan islam menarik investor dengan sukses bukan hanya tergantubg pada tingkat kemampuvan lembaga tersebut menghasilkan keuntungan, tetapi juga pada persepsi bahwa lembaga tersebut secara sungguh-sungguh memperhatikan batas-batas yang digariskan oleh islam (Arifin, 2009:16).

\section{Tingkat Bagi Hasil Deposito}

Bagi hasil adalah sistem pembagian hasil usaha dimana pemilik modal bekerja sama dengan pengelola modal utuk melakukan kegiatan usaha. Apabila kegiatan usaha menghasilkan keuntungan maka dibagi berdua ketika mengalami kerugian ditanggung bersama pula. Sistem bagi hasil menjamin adanya keadilan dan tidak ada pihak yang tereksploitasi (Natalia, et.al 2014)

\section{Dana Pihak Ketiga}

Perbankan merupakan salah satu tulang punggung perekonomian suatu Negara karena memiliki fungsi intermediasi antara pemilik modal dengan pengguna dana pihak ketiga yang dipercaya. Apabila terjadi peningkatan pada jumlah dana pihak ketiga menunjukkan tingkat kepercayaan dari masyarakat yang semakin baik kepada bank syariah. Danadana yang dihimpun dari masyarakat merupakan sumber dana terbesar tang paling diandalkan bank dalam memenuhi kebutuhan hidupnya. Hal nini sesuai dengan fungsi bank syariah sebagai penghimpun dana masyarakat.

\section{Pembiayaan Mudharabah}

Mudharabah mengandung arti sebagai ungkapan penyerahan harta yang dimiliki seseorang kepada orang lain sebagai kegiatan usaha. Keuntungan yang diperoleh atas usaha yang dilakukan dibagi bersama, sedangkan jika terjadi kerugian maka hal tersebut ditanggung oleh pemilik modal. Menurut Syara', mudharabah adalah akad dua pihak untuk bekerja sama dalam perdagangan, dimana salah satu pihak menyerahkan dana kepada pihak lainnya sebagai modal usaha yang halal dan produktif (Fadhila, 2015).

Menurut UU RI No.21 Tahun 2008 tentang perbankan Syariah pasal 19 ayat (11) yang dimaksud dengan "Akad Mudharabah" dalam pembiayaan adalah akad kerja sama suatu usaha antara pihak pertama (malik, shahibul mal, atau bank syariah) yang menyediakan seluruh modal dan pihak kedua mudharib atau pengelola dana dengan membagi keuntungan usaha sesuai dengan kesepakatan yang dituangan dalam Akad. Seddangkan kerugian ditanggung sepenuhnya oleh Bank Syariah kecuali jika pihak kedua melakukan kesalahan yang disengaja, lalai atau menyalahi perjanjian.

\section{Laporan Kevangan}

Dalam suatu perusahaan laporan keuangan sangat diperlukan untuk mengetahui kinerja dari industri bank syariah, dan akan lebih sulit bagi bank syariah tersebut dalam merencanakan 
industri di masa yang akan datang jika tidak mengetahui kinerja usaha yang dijalankan saat ini. Definisi laporan keuangan menurut beberapa ahli, menurut menurut Munawir (2001: 5) diartikan sebagai hasil dari proses akuntansi yang dapat dipergunakan sebagai alat untuk komunikasi antara data keuangan atau aktivitas suatu perusahaan dengan pihak-pihak yang berkepentingan dengan aktivitas perusahaan. Kieso dkk (2004: 2) laporan keuangan merupakan sarana utama untuk mengomunikasikan informasi keuangan kepada pihak diluar perusahaan.

\section{Analisis Laporan Keuangan}

Analisis rasio keuangan merupakan salah satu alat bantu yang penting untuk mengukur kinerja internal dari suatu badan usaha. Analisis rasio sangat bermanfaat bagi manajemen untuk perencanaan dan pengevaluasian prestasi atau kinerja perusahaan bila dibandingkan dengan rata-rata industri.

\section{Hipotesis}

1. Tingkat bagi hasil deposito berpengaruh signifikan terhadap dana pihak ketiga.

2. Dana pihak ketiga berpengaruh signifikan terhadap pembiayaan mudharabah.

3. Tingkat bagi hasil deposito berpengaruh signifikan terhadap pembiayaan mudharabah.

\section{Model Analisis}

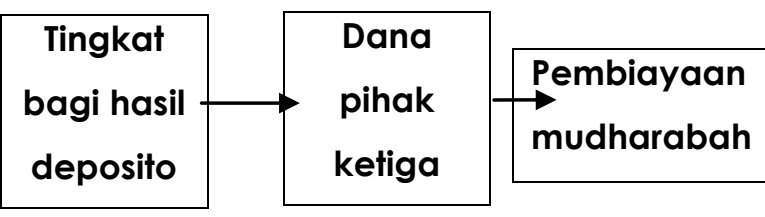

Pada penelitian ini menggunakan persamaan structural untuk variable endogen intervening ( $Z$ ) dengan persamaan berikut:

$$
z=b_{1} x+e
$$

Penelitian ini juga menggunakan persamaan structural untuk variable endogen $(Y)$ dengan persamaan berikut:

$$
Y=b_{2} Z+b_{3} X+e
$$

Di mana:

Z: Dana Pihak Ketiga

Y: Pembiayaan Mudharabah

$\mathrm{X}$ : Tingkat Bagi Hasil

E: Standart eror

$b_{1} b_{2} b_{3}=$ Koefisien jalur

III. METODE PENELITIAN

\section{Rancangan Penelitian}

Penelitian ini menggunakan rancangan penelitian berdasarkan pendekatan kuantitatif. Penelitian ini akan membuktikan pengaruh tingkat bagi hasil deposito melalui variable intervening dana pihak ketiga terhadap pembiayaan mudharabah.

\section{Identifikasi Variabel \\ Variabel eksogen juga sering disebut sebagai variable bebas dalam penelitian ini adalah tingkat bagi hasil. Variabel endogen intervening dalam penelitian adalah dana pihak ketiga sedangkan variable endogen dalam}


Setiyoaji, et al/Jurnal Ekonomi Syariah Teori dan Terapan Vol. 6 No. 5 Mei 2019: 957-967; TINGKAT BAGI HASIL DEPOSITO MELALUI VARIABEL INTERVENING DANA PIHAK KETIGA TERHADAP PEMBIAYAN MUDHARABAH BANK SYARIAH

penelitian ini adalah Pembiayaan mudharabah

\section{Definisi Operasional}

Variabel-variabel yang digunakan tersebut definisi operasionalnya adalah sebagai berikut:

1. Tingkat Bagi Hasil

Sistem bagi hasil merupakan sistem pembagian hasil usaha dimana pembagian hasil usaha dimana pemilik modal bekerja sama dengan pengelola modal untuk melakukan kegiatan usaha (Natalia, et.al. 2014). Dalam penelitian ini bagi hasil diukur menggunakan equivalent ratio deposito bulanan.

2. Dana Pihak Ketiga

Dana pihak ketiga adalah dana bank yang bersumber dari luar bank atau dari masyarakat berbentuk giro, tabungan, deposito, dan pinjaman, serta bentuk lain yang dipersamakan dengan itu (Pratiwi dan norita, 2013). Dana pihak ketiga diambil bulanan dengan komposisi diambil satu bulan karena dianggap dominan.

3. Pembiayaan Mudharabah

Pembiayaan mudharabah adalah akad dua pihak untuk bekerja sama dalam perdagangan, dimana salah satu pihak menyerahkan dana kepada pihak lainnya sebagai modal usaha yang halal dan produktif Fadhila, 2015). Pembiayaan mudharabah diukur menggunakan nilai mudharabah pada laporan keuangan periode 2012-2016.

\section{Jenis dan Sumber Data}

Data yang digunakan dalam penelitian ini adalah data sekunder. Data sekunder dala penelitian ini bersumber dari laporan keuangan industri perbankan syariah perbulan yang diterbitkan di website resmi statistik perbankan syariah di website resmi di Bank Indonesia pada tahun 2012-2016.

\section{Populasi dan Sampel}

Populasi dalam penelitian ini adalah Industri Bank Syariah di Indonesia Bank Umum Syariah (BUS) dan Unit Usaha Syariah (UUS) yang terdaftar tahun 20122016. Metode pemilihan sampel yang digunakan dalam penelitian ini adalah teknik purposive sampling. Sampel yang digunakan dalam penelitian ini berjumlah 60 sampel yang diambil dari website Bank Indonesia maupun Otoritas Jasa Keuangan (OJK) selama tahun 2012-2016

\section{Teknik Analisis}

Teknik analisis data yang digunakan dalam penelitian ini adalah analisis jalur (Path Analysis). Metode analisis data adalah suatu metode yang digunakan untuk mengolah hasil penelitian guna memperoleh suatu kesimpulan. Dengan melihat kerangka pemikiran teoritis, maka teknik analisis data yang digunakan dalam penelitian ini adalah analisis kuantitatif dengan path analysis menggunakan program AMOS 4. Ghozali (2011) menjelaskan untuk menguji pengaruh variabel intervening digunakan metode analisis jalur (Path Analysis). Analisis jalur merupakan pengembangan 
Setiyoaji, et al/Jurnal Ekonomi Syariah Teori dan Terapan Vol. 6 No. 5 Mei 2019: 957-967; TINGKAT BAGI HASIL DEPOSITO MELALUI VARIABEL INTERVENING DANA PIHAK KETIGA TERHADAP PEMBIAYAN MUDHARABAH BANK SYARIAH

dari analisis regresi linear berganda, atau penggunaan analisis regresi untuk mengetahui adanya hubungan kausalitas antar variabel. Hubungan langsung maupun hubungan tidak langsung antar variabel dalam model juga dapat diukur dengan menggunakan analisis jalur. Dalam model persamaan structural penelitian ini terdapat variabel eksogen, variabel endogen, dan variabel intervening.

\section{Uji Outlier}

Uji outlier adalah kondisi observasi dari suatu data yang memiliki karakteristik unik yang terlihat sangat berbeda jauh dari observasi-observasi lainnya dan muncul dalam bentuk nilai ekstrim baik dalam variabel tunggal maupun variabel kombinasi. Dengan demikian jika data tidak berdistribusi normal, maka dilakukan eliminasi data oulier, sebaliknya jika data sudah berdistribusi normal maka tidak diperlukan eliminasi data. Uji outlier dilakukan dengan mengamati nilai $Z$ score. Data dikatakan tidak oulier jika memiliki nilai minimum dan maksimum $Z$ score $< \pm 3$ (Ferdinand, 1999) .

\section{Uji Normalitas}

Uji normalitas dilakukan untuk mengetahui apakah suatu data normal atau tidak. Uji ini digunakan untuk mengetahui apakah variable bebas dengan variable terikat mempunyai distribusi normal atau tidak. Uji normalita dilakukan dengan pengamatan nilai $C R$ Skewness (kemiringan) dan CR Kurtosis (Keruncingan). Data dikatakan normal jika mempunyai nilai CR skewness dan kurtosis $\pm 2,58$ dengan tingkat signifikansi $5 \%$. Normalitas menjadi persyaratan mutlak dalam pengujian path analysis.

\section{Melakukan analisis Squared Multiple Correlation}

Koefisien yang menunjukkan besarnya korelasi antara variable eksogen dengan variable endogen. Koefisien tersebut diprosentase kanuntuk memperoleh koefisien determinasi yang dapat menunjukkan besarnya variasi endogen yang dijelaskan oleh variable eksogen

Melakukan analisis pengaruh langsung, tidak langsung dan total

Untuk mengetahui kekuatan pengaruh antar model. Pengaruh langsung didapatkan dari koefisien beta dalam analisis jalur, pengaruh tidak langsung didapatkan berdasarkan nilai beta dari variabel yang dilalui dan pengaruh total didapatkan dari hasil penjumlahan kedua pengaruh tersebut.

\section{HASIL PENELITIAN DAN \\ PEMBAHASAN}

PEMILIHAN MODEL ESTIMASI DATA PANEL

\section{UJI Outlier}

Uji outlier adalah data yang memiliki karakteristik unik yang terlihat sangat jauh dari observasi-observasi lainnya dan muncul dalam bentuk nilai ekstrim. Outlier merupakan hasil-hasil observasi yang menunjukkan jarak sebuah observasi dari rata-rata semua variabel dalam sebuah ruang multidimensional (hair, et.al., 1998). Untuk menghitung jarak 
mahalanobis berdasarkan nilai chi kuadrat pada derajat bebas sebesar indikator yang digunakan dalam setiap variabel.

Penelitian ini terdapat 3 indikator, oleh karenanya nilai Chi Kuadrat $\chi^{2}$ tabel $(0,001: 3)=16,266$. Berdasarkan hasil uji multivariate outlier menunjukkan bahwa nilai Mahalanobis yang dihasilkan adalah antara 0,337 sampai dengan 10.165 (Lampiran 2), karena nilai Mahalanobis yang dihasilkan dibawah $\chi^{2}$ tabel, maka tampilan data yang dianalisis dapat menyimpulkan bahwa tidak terdapat outlier multivariate.

\section{Uji Normalitas}

Uji normalitas sebaran dilakukan dengan Skewness Value dari data yang digunakan yang biasanya disajikan dalam statistik deskriptif. Nilai statistik untuk menguji normalitas itu disebut z-value. Bila nilai-z lebih besar dari nilai kritis maka dapat diduga bahwa distribusi data adalah tidak normal. Nilai kritis dapat ditentukan berdasarkan tingkat signifikansi $0,01(1 \%)$ yaitu sebesar $\pm 2,58$.

Tabel 1

\section{Normalitas Data}

\begin{tabular}{|c|cccc|}
\hline Variable & Skew & c.r. & kurtosis & c.r. \\
& & & & \\
\hline X & -.438 & -1.385 & -.239 & -.377 \\
Z & -.113 & -.356 & -.855 & - \\
Y & 1.352 & & & \\
Multivariate & -.740 & -2.2339 & -.585 & -.529 \\
& & & -.748 & -.529 \\
& & & & \\
\hline
\end{tabular}

Sumber: Lampiran 2

Hasil uji menunjukkan bahwa nilai c.r. multivariate berada didalam selang \pm 2,58 itu berarti asumsi normalitas terpenuhi.

\section{Uji Multicollinearity dan Singularity}

Untuk mengetahui apakah terdapat multicolearity atau singularity dalam sebuah kombinasi variabel, perlu mengamati determinan matriks kovarians. Determinan yang benar-benar kecil mengindikasikan adanya multicolearity atau singularity sehingga data tidak dapat digunakan untuk analisis yang sedang dilakukan.

Angka determinan matriks kovarians pada penelitian ini sebesar 0,827634797460265 lebih dari 0 , berarti tidak terjadi multicolearity atau singularity dalam data.

\section{Uji Hipotesis}

Setelah dilakukan pengujian asumsi, selanjutnya dilakukan pengujian hipotesis pada data observasi. Pengujian hipotesis dilakukan dengan mengkonversi diagram jalur yang telah dibuat sebelumnya menjadi sebuah gambar persamaan structural dengan menggunakan software AMOS (Analysis of Moment Structure). Hasil konevrsi tersebut ditampilkan dalam gambar 4.4 berikut

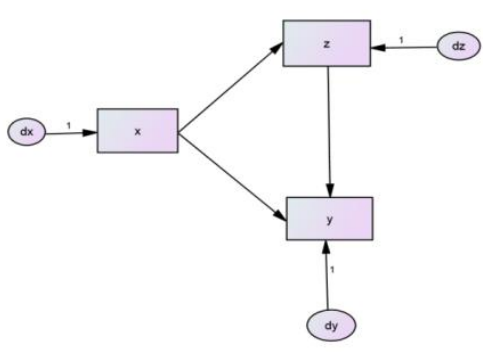

Gambar 2

Gambar Persamaan Struktural 
$X:$ Tingkat Bagi Hasil

Z: Dana Pihak Ketiga

Y: Pembiayaan Mudharabah

Berdasarkan gambar 2 terlihat besaran koefisien jalur yang meliputi tingkat bagi hasil deposito terhadap dana pihak ketiga sebesar 0,30, variable dana pihak ketiga terhadap pembiayaan mudharabah sebesar 0,09 serta variable dana pihak ketiga terhadap pembiayaan mudharabah sebesar 0,87 .

\section{Analisis Pengaruh Langsung, Pengaruh}

\section{Tidak Langsung dan Pengaruh Total}

Analisis pengaruh langsung, pengaruh tidak langsung dan pengaruh total dari variabel yang diteliti dilakukan untuk mengetahui kekuatan pengaruh antar konstruk pada ketiga jenis pengaruh tersebut. Dengan menggunakan AMOS, berikut ini ditampilkan hasil analisis pengaruh langsung, pengaruh tidak langsung dan pengaruh total dari masingmasing variabel :

\begin{tabular}{|c|c|c|}
\hline $\begin{array}{l}\text { Jenis } \\
\text { pengaruh }\end{array}$ & $\begin{array}{l}\text { Variabel } \\
\text { Pengaruh }\end{array}$ & $\begin{array}{l}\text { Std } \\
\text { Estimate }\end{array}$ \\
\hline Langsung & $\begin{array}{l}\text { Tingkat bagi } \\
\text { hasil } \rightarrow \\
\text { deposito } \\
\text { Dana Pihak } \\
\text { ketiga } \\
\text { Tingkat bagi } \\
\text { hasil } \rightarrow \\
\text { deposito } \\
\text { Pembiayaan } \\
\text { mudharabah } \\
\text { Dana pihak }\end{array}$ & $\begin{array}{l}0.099 \\
0.878\end{array}$ \\
\hline
\end{tabular}

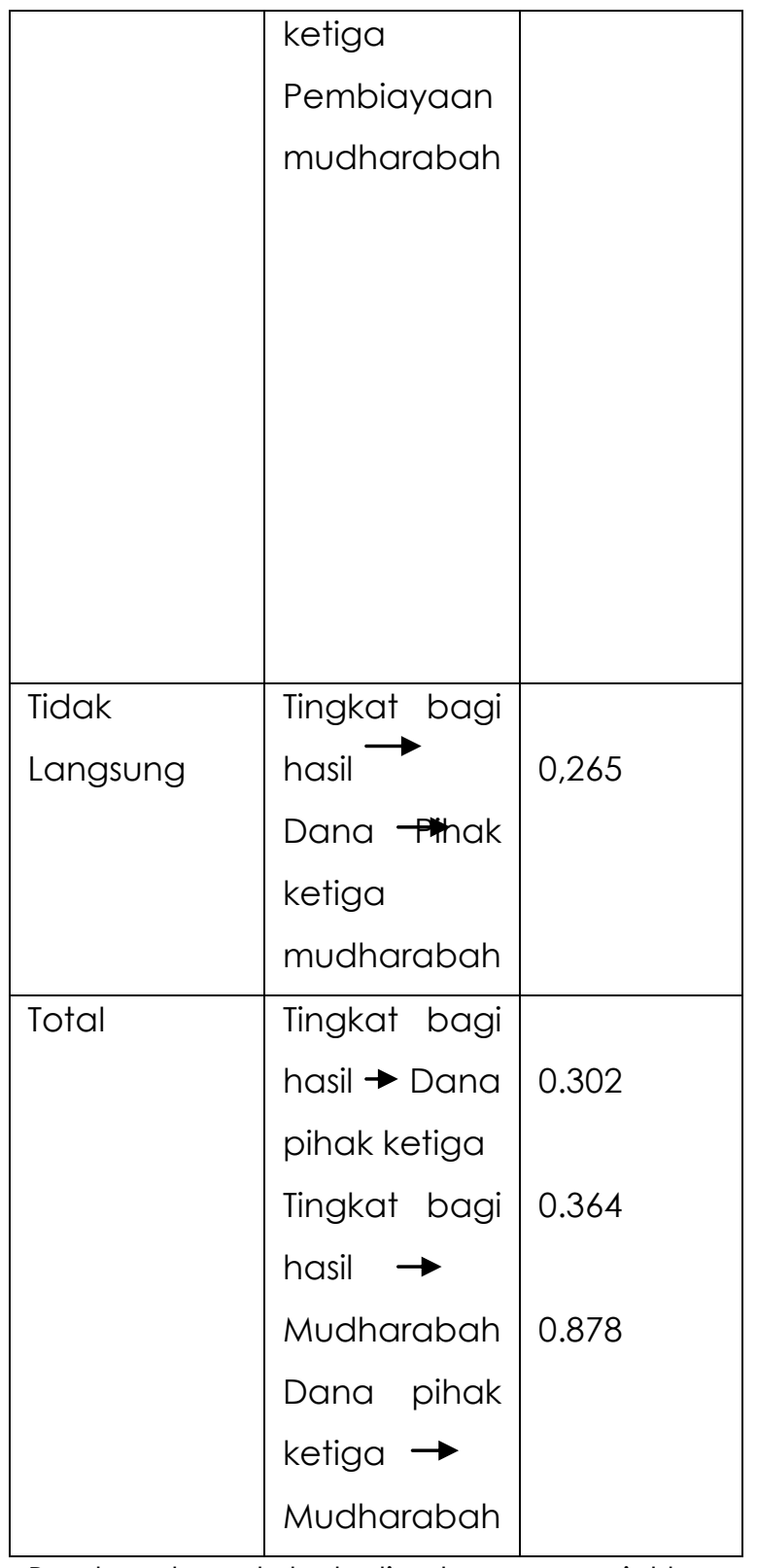

Berdasarkan tabel di atas menunjukkan bahwa besarnya pengaruh tingkat bagi hasil deposito terhadap mudharabah melalui dana pihak ketiga sebesar 26,5\% dan variabel dana pihak ketiga terbukti sebagai variabel intervening antara tingkat bagi hasil deposito dengan mudharabah.

PEMBAHASAN

Pengaruh secara Parsial Tingkat Bagi Hasil Deposito terhadap Dana Pihak Ketiga 
Setiyoaji, et al/Jurnal Ekonomi Syariah Teori dan Terapan Vol. 6 No. 5 Mei 2019: 957-967; TINGKAT BAGI HASIL DEPOSITO MELALUI VARIABEL INTERVENING DANA PIHAK KETIGA TERHADAP PEMBIAYAN MUDHARABAH BANK SYARIAH

Variabel tingkat bagi hasil deposito berpengaruh positif terhadap dana pihak ketiga tingkat pengaruh sebesar 0.302 sedangkan nilai t-hitungnya sebesar 2,436 dengan probabilitas sebesar 0,015 . Karena nilai probabilitas kurang dari $5 \%$ maka dapat disimpulkan bahwa tingkat bagi hasil deposito berpengaruh positif signifikan terhadap dana pihak ketiga, yang artinya semakin tinggi tingkat bagi hasil deposito maka dana pihak ketiga semakin tinggi.

\section{Pengaruh secara Parsial Dana Pihak Ketiga terhadap Pembiayaan Mudharabah}

Variabel dana pihak ketiga terhadap pembiayaan mudharabah tingkat pengaruh sebesar 0,878 dengan probabilitas sebesar 0,000 sedangkan nilai t-htitungnya sebesar 15,728. Hal ini berarti setiap kenaikan dana pihak ketiga sebesar satu satuan maka akan meningkatkan pembiayaan mudharabah sebesar 0,878. Dengan demikian, hasil analisis kuantitatif dalam penelitian ini sesuai dengan penelitian sebelumnya, yaitu dana pihak ketiga berpengaruh positif terhadap pembiayaan mudharabah. Menurut arnan dan kurniawasih (2014) salah satu sumber dana yang dapat digunakan untuk pembiayaan adalah simpanan masyarakat (DPK).

Pengaruh secara Parsial Tingkat Bagi Hasil deposito terhadap Pembiayaan Mudharabah
Variabel tingkat bagi hasil deposito terhadapa pembiayaan mudharabah tingkat pengaruh sebesar 0,099 dengan nilai probabilitas sebesar 0,076 sedangkan nilai t-hitungnya sebesar 1,773. Karena nilai probabilitas yang dihasilkan lebih dari $5 \%$ maka dapat disimpulkan bahwa tingkat bagi hasil deposito tidak berpengaruh signifikan terhadap pembiayaan mudharabah, yang artinya tingginya tingkat bagi hasil deposito tidak berdampak nyata pada peningkatan pembiayaan mudharabah. Oleh karena itu, hasilnya tidak signifikan atau tidak ada pengaruh.

\section{SIMPULAN}

Berdasarkan hasil analisis dan pembahasan pada bab sebelumnya, maka dapat disimpulkan sebagai berikut:

1. Tingkat bagi hasil deposito berpengaruh positif signifikan terhadap dana pihak ketiga industri bank syariah selama periode 2012-2016 dengan koefisien jalur 0,302. Hal itu menunjukkan bahwa setiap terjadi kenaikan sebesar satu satuan pada jumlah tingkat bagi hasil deposito maka akan meningkatkan jumlah dana pihak ketiga sebesar 0,302 satuan.

2. Tingkat bagi hasil deposito tidak signifikan pengaruh terhadap pembiayaan mudharabah bank syariah selama periode 2012-2016.

3. Dana pihak ketiga berpengaruh positif signifikan terhadap pembiayaan mudharabah industri bank syariah selama periode 2012-2016 dengan 
koefisien jalur 0,878. Hal itu menunjukkan setiap terjadi kenaikan sebesar satu satuan pada jumlah dana pihak ketiga maka akan meningkatkan jumlah pembiayaan mudharabah.

4. Besarnya pengaruh tingkat bagi hasil deposito dan dana pihak ketiga terhadap pembiayaan mudharabah sebesar $83,3 \%$ sedangkan sisanya $16,7 \%$ dijelaskan oleh variabel lain yang tidak dibahas pada penelitian ini. Sedangkan variabel yang paling dominan mempengaruhi pembiayaan mudharabah adalah dana pihak ketiga.

5. Besarnya pengaruh tingkat bagi hasil deposito terhadap pembiayaan mudharabah melalui dana pihak ketiga sebesar $26,5 \%$ dan variabel dana pihak ketiga terbukti sebagai variabel intervening antara tingkat bagi hasil deposito dengan pembiayaan mudharabah.

Saran yang dapat diberikan dari penelitian ini adalah:

1. Bank syariah harus memperhatikan dengan baik bagi hasil bank syariah untuk menarik minat masyarakat. Hal ini dikarenakan setiap nasabah pasti akan mempertimbangkan tingkat imbalan bagi hasil yang diperoleh ketika melakukan sebuah kegiatan investasi pada bank syariah. Oleh karena itu, tingkat bagi hasil menjadi aspek penting untuk bisa menarik minat nasabah. Ketika tingkat bagi hasil yang ditawarkan oleh bank syariah tinggi, maka masyarakat akan cenderung menyimpan vangnya di bank syariah.

2. Bank syariah harus tetap menjaga kestabilitas dana pihak ketiga sebab dana bank yang optimal akan mampu menyediakan ruang gerak yang cukup bagi pihak perbankan syariah untuk menyalurkan dan menyimpan dana bank syariah.

3. Bank Indonesia harus tetap memperhatikan dan mengawasi tingkat kesehatan bank syariah yang salah satunya diukur dari tingkat bagi hasil deposito, dana pihak ketiga, pembiayaan mudharabah agar bank syariah tersebut tetap dapat menjalankan aktivitas perbankan dengan baik.

Bagi penelitian selanjutnya, perlu menambahkan variable-variabel penelitian lain yang lebih berpengaruh terhadap pembiayaan mudharabah bank umum syariah dan periode penelitian yang lebih panjang, sehingga dapat memperoleh hasil yang maksimal dan dapat di generalisasikan.

\section{DAFTAR PUSTAKA}

Antonio, M. S. (2001). Bank Syariah: Dari teori Ke Praktik . Jakarta: Gema Insani Press.

Anjani, R., \& Hasmarani, M. I. (2016). Pengaruh Pembiayaan Mudharabah, Musyarakah Dan Murabahah Terhadap Profitabilitas BPRS Di Indonesia Periode 2012- 
2015.Syariah Paper Accounting FEB UMS.

Arifin, Z. (2009). Dasar-dasar Manajemen Bank Syariah. Tangerang: Azkia Publisher.

Arnan dan Kurniawasih. (2014). Pengaruh Jumlah Dana Pihak Ketiga dan Tingkat Non-Performing Financing Terhadap Pembiayaan Mudharabah pada Bank Umum Syariah di Indonesia.Proceedings SNEB 2014: 2.

Aswad. (2014). Analisis Bagi Hasil Financing dalam Perbankan Syariah. Vol. I, No. 1, Oktober 2014.

Bahri. (2015). Model Penelitian Kuantitatif Berbasis SEM-Amos. Yogyakarta: Deepublish

Barus, A. C., \& Sulistyo, D, (2011), Hubungan Efisiensi Operasional Dengan Kinerja Profitabilitas Pada Sektor Perbankan Yang Go Public Di Bursa Efek Indonesia.Jurnal Wira Ekonomi Mikroskil, Vol. 1, No. 02, hal 89-97.

Chair, W. 2014.Riba Dalam Perspektif Islam.latishadia Vol. 1 No. 1

Daniar. 2015. Asuransi Perspektif Al-Qur'an. Islamic Economic JournalVol. 1, No. 2 ISSN 2460-1896

Fadhila, N. (2015). Analisis Pembiayaan Mudharabah Dan Murabahah Terhadap Laba Bank Syariah Mandiri.Jurnal Riset Akuntansi Dan Bisnis, Vol. 15, No. 1.

Fahrul, F., Arfan, M., \& Darwanis. (2012). Pengaruh Tingkat Risiko
Pembiayaan Musyarakah Dan Pembiayaan Murabahah Terhadap Tingkat Profitabilitas Bank Syariah (Studi Pada Bank Aceh Syariah Cabang Banda Aceh). Jurnal Akuntansi Pascasarjana Universitas Syiah Kuala, Vol. 2, No. 1.

Ferdiansyah. (2015). Pengaruh Rate Bagi Hasil Dan BI Rate Terhadap Dana Pihak Ketiga Perbankan Syariah (Studi Pada Bank Pembiayaan Rakyat Syariah Yang Terdaftar Di Bank Indonesia).JOM Fekon, Vol. 2, No. 1.

Gani, I., \& Amalia, S. 2015.Alat Analisis Data: Aplikasi Statistik untuk Penelituan Bidang Ekonomi dan Sosial. Yogyakarta: Andi.

Ghazali, I. 2011. Model Persamaan Struktural Konsep dan Aplikasi dengan Program Amos 19,0. Semarang: Undip

Gustina, 2011. Islamic Banking System: Studi Analisis Perkembangan Perbankan Syariah Di Indonesia.Jurnal Akuntansi \& Manajemen Vol 6 No.1 ISSN 18583687

Hadad, M. D. 2017. Laporan Perkembangan Keuangan Syariah 2016. OJK (Otoritas jasa keuangan) 